\title{
EVALUASI PROSES PEMBELAJARAN MATEMATIKA KELOMPOK BELAJAR PAKET C HARAPAN KECAMATAN GEMOLONG KABUPATEN SRAGEN
}

\author{
Ngatman, Mardiyana, Mania Roswitha
}

\begin{abstract}
Abstrak
Penelitian ini bertujuan untuk mengevaluasi dan mendiskripsikan 1) Proses pembelajaran matematika di Kejar Paket C PKBM Harapan Kecamatan Gemolong, 2) Pelaksanaan kurikulum di Kejar Paket C PKBM Harapan Kecamatan Gemolong, 3) Kendala-kendala dalam proses pembelajaran matematika di Kejar Paket C PKBM Harapan Kecamatan Gemolong, 4) Untuk memberikan rekomendasi solusi terhadap kendala yang muncul pada proses pembelajaran matematika Kejar Paket C PKBM Harapan Kecamatan Gemolong.

Penelitian ini adalah penelitian evaluatif dengan pendekatan deskritif kualitatif. Sumber informasi dalam penelitian ini adalah Kepala Sekolah, siswa atau warga belajar, guru atau tutor Kejar Paket C Harapan Kecamatan Gemolong Kabupaten Sragen. Teknik pengumpulan data yang digunakan adalah teknik wawancara, observasi kelas dan dokumentasi. Teknik analisis data yang digunakan adalah teknik alur yang meliputi pengumpulan data, penyajian data, reduksi data dan penarikan kesimpulan.

Dari hasil analisis data dapat disimpulkan bahwa: 1) proses pembelajaran matematika di kelas Kejar Paket C Harapan Kecamatan Gemolong belum berlangsung kondusif, guru atau tutor menggunakan metode yang monoton sehingga siswa merasa jenuh, 2) pelaksanaan kurikulum di Kejar Paket C Harapan telah sesuai dengan ketentuan Kurikulum Pendidikan Kesetaraan, 3) kendala-kendala yang dihadapi dalam proses pembelajaran antara lain kebanyakan siswa membawa anak-anak mereka ke dalam kelas, guru jarang mengikuti workshop model pembelajaran, tidak tersedia buku pegangan siswa.

Rekomendasi atas kendala yang dihadapi dalam proses pembelajaran adalah: 1) menganjurkan siswa agar tidak membawa anak-anak ke dalam kelas, 2) mengikutkan guru dalam workshop model pembelajaran, 3) pengadaan buku pegangan siswa secara bertahap.
\end{abstract}

Kata kunci : Evaluasi Proses, kelompok belajar Paket C, pembelajaran matematika

\section{PENDAHULUAN}

Pendidikan merupakan sektor penting yang berperan aktif dalam meningkatkan pembangunan bangsa. Pendidikan mengandung makna yang esensial sebagai proses memanusiakan manusia sebagai pribadi, anggota keluarga, anggota masyarakat dan makhluk Tuhan Yang Maha Esa. Hal ini mengandung arti bahwa pendidikan memiliki keterkaitan dengan berbagai upaya untuk meningkatkan kualitas hidup manusia secara utuh. Usaha pendidikan diwujudkan dalam kegiatan pengembangan seluruh potensi manusia kearah yang lebih dewasa dan fungsional sehingga secara aktif dan kreatif dapat melahirkan sumber daya manusia yang sesuai dengan tuntutan jaman dalam kehidupan.

Kebodohan seringkali disebut-sebut sebagai penyumbang terbesar terjadinya kemiskinan dan keterbelakangan bangsa ini. Memang tidak dipungkiri bahwa kurangnya pengetahuan seseorang yang diakibatkan oleh kurangnya pendidikan menjadikan mereka tidak bisa menerima perkembangan ilmu dan teknologi. Pendidikan berlangsung sepanjang hayat sesuai dengan perkembangan tuntutan tugas kehidupannya, dan perkembangan masyarakat yang 
semakin luas, semakin global bahkan semakin kompleks. Oleh karena itu setiap individu harus memiliki kemampuan belajar sepanjang hayat untuk dapat menerima dan mengikuti setiap perkembangan limu pengetahuan dan teknologi. Pendidikan sepanjang hayat harus selalu dilakukan secara terus menerus sehingga dapat meningkatkan kecakapan hidupnya.

Berbagai wahana untuk meningkatkan kemapuan belajar peserta didik telah dilakukan oleh pemerintah sebagai pemegang otoritas kebijakan pendidikan. Pendidikan dapat diperoleh di berbagai lembaga formal, non formal dan informal. Pendidikan melalui lembaga formal telah dibentangkan secara luas oleh pemerintah, bahkan pemerintah mengeluarkan kebijakan wajib belajar 9 tahun sebagai salah satu cara untuk meningkatkan pendidikan bangsa Indonesia. Dengan kebijakan ini diharapkan setiap warga negara Indonesia memiliki pendidikan sekurang-kurangnya Sekolah Menengah Pertama (SMP). Dengan bekal pendidikan SMP ini diharapkan setiap warga negara Indonesia mampu menghadapi tantangan jaman yang semakin global . Melalu pendidikan non formal pemerintah menggulirkan program Pendidikan Luar Sekolah sehingga sekarang banyak dijumpai kelompok-kelompok belajar (Kejar) Paket A setara dengan Sekolah Dasar (SD), Kejar paket B setara dengan Sekolah Menengah Pertama (SMP) dan Kejar Paket C setara dengan Sekolah Menengah Atas (SMA). Melalui pendidikan informal semakin menjamurnya lembaga-lembaga pendidikan keterampilan, kursus-kursus berbagai bidang sehingga warga Negara dapat memilih dan menikmati pendidikan secara layak sesuai dengan kondisi masing-masing.

Setiap jalur pendidikan baik formal, non formal maupun informal pada dasarnya memiliki tugas dan fungsinya masingmasing dengan satu muara yaitu mencerdaskan kehidupan bangsa. Namun demikian masing-masing jalur tersebut memiliki tugas dan ciri khas tertentu. Pada jalur Pendidikan Luar Sekolah, dianut prinsip belajar sepanjang hayat yang berarti setiap warga masyarakat dirangsang untuk terus belajar walaupun dengan cara, waktu, tempat dan tingkat yang berbeda-beda, keleluasaan untuk memilih sangat terbuka sesuai keadaan masyarakat sendiri.

Dalam pembelajaran matematika banyak guru yang mengeluh kurangnya sarana dan prasarana yang mendukung bagi terciptanya pembelajaran matematika yang lebih baik. Hal ini terlihat dari sarana kelas yang apa adanya, bahkan kelas Kejar Paket C PKBM (Pusat Kegiatan Belajar Masyarakat) Harapan Kecamatan Gemolong sering meminjam di rumah-rumah penduduk untuk proses pembelajaran. Pada proses pembelajaran matematika guru memegang peranan yang sentral. Dengan keterbatasan sarana dan prasarana yang ada bagaimana guru dapat melakukan inovasi dan kreatifitas sehingga pada gilirannya dapat meningkatkan kemampuan peserta didik. Perbedaan intelektual dan penguasaan 
materi peserta didik dari sekolah formal dan non formal juga harus diperhatikan, kurikulum yang digunakan pun berbeda, proses pembelajaran juag harus berbeda. Dengan demikian pada Kejar Paket C ini dibutuhkan guru yang profesional dalam bidangnya dalam mengajarkan konsepkonsep matematika pada peserta didik, karena memang peserta didik memiliki karakteristik yang berbeda dengan siswa di sekolah formal.

\section{EVALUASI}

PROGRAM

\section{PEMBELAJARAN}

Evaluasi program sering disalah artikan, dianggap sebagai kegiatan untuk mencari kesalahan dan kelemahan program, seseorang atau kelompok yang melaksanakan program (Djuju Sudjana:2006). Evaluasi program diadakan bukan untuk menetapkan baik-buruknya suatu program karena kegiatan tersebut termasuk dalam kategori keputusan.

Syamsu Mappa dalam Duju Sudjana (2006) mendefinisikan evaluasi program pendidikan luar sekolah sebagai kegiatan yang dilakukan untuk menetapkan keberhasilan dan kegagalan suatu program pendidikan. Sejalan dengan pengertian diatas, Mugiadi (1980) menjelaskan bahwa evaluasi program adalah upaya untuk mengumpulkan informasi mengenai suatu program, kegiatan, atau proyek. Informasi tersebut berguna bagi pengambilan keputusa, antara lain untuk memperbaiki program, menyempurnakan program lanjutan, menghentikan suatu program, atau menyebarluaskan gagasan yang mendasarisuatu program atau kegiatan.

Berdasarkan berbagai pengertian sebagaimana dikemukakan di atas maka evaluasi program dapat didefinisikan sebagai kegiatan sistematis untuk mengumpulkan, mengolah, menganalisis dan menyajikan data sebagai masukan untuk pengambilan keputusan. Dalam pengertian ini data adalah fakta, keterangan, atau informasi yang darinya dapat ditarik generalisasi.

Pengertian evaluasi program sebagaimana disampaikan di atas menunjukkan adanya keterkaitan dengan penelitian. Artinya bahwa evaluasi program dan penelitian memliki hubungan erat antara keduanya. Untuk mengetahui tingkat ketercapaian pelaksanaan program perlu dilakukan penelitian evaluasi pelaksanaan program kurikulum, begitu pula untuk mengetahui ketercapaian tujuan proses pembelajaran matematika pada Kejar Paket C.

\section{PEMBELAJARAN MATEMATIKA DI KEJAR PAKET C}

Matematika timbul oleh pola pikir manusia, yang berhubungan dengan ide, proses, dan penalaran. Matematika terdiri atas empat kawasan. yaitu: aritmatika, aljabar, geometri dan analisis. Matematika adalah bahasa simbolis yang fungsi praktisnya untuk mengekspresikan hubungan- hubungan kuantitatis dan keruangan sedangkan fungsi teoritisnya 
adalah untuk memudahkan berpikir. Belajar matematika dapat membantu serta melatih siswa untuk mengasah fungsi otak kiri. Mengasah fungsi otak kiri, yaitu bahwa dengan belajar matematika dapat melatih siswa berpikir logis, analitis, kritis, detail, runtut, runtun, sistematis, serta memahami adanya kemungkinan terjadi dan menilai sesuatu bukti.

Matematika adalah alat yang dapat memperjelas dan menyederhanakan suatu keadaan atau situasi melalui abstraksi, idealisasi atau generalisasi untuk suatu studi ataupun pemecahan masalah. Hal inilah sehingga menjadikan matematika, paling tidak membantu manusia secara individu melaksanakan studi dibanyak bidang dan berhasil memecahkan permasalahan kehidupan. Matematika yang abstrak dikuasai sejak SD agar siswa sudah terlatih untuk berpikir sistematik seperti yang terdapat dalam matematika.

Menurut Wina Sanjaya (2006:133) pembelajaran harus berorientasi pada aktivitas siswa. Artinya, sistem pembelajaran menempatkan siswa sebagai subyek belajar. Oleh karena itu, proses pendidikan bukan hanya mengembangkan intelektual saja, tetapi mencakup seluruh potensi yang dimiliki peserta didik.

\section{KOMPONEN EVALUASI PROSES} PEMBELAJARAN MATEMATIKA KEJAR PAKET C

Evaluasi proses pembelajaran matematika pada Kejar Paket C dilakukan dengan cara melakukan pengamatan, wawancara dan angket. Adapun komponen yang diteliti adalah proses pembelajaran, yang merupakan implementasi dari RPP, yang meliputi kegiatan pendahuluan, kegiatan inti, dan kegiatan penutup.

a. Pembelajaran Tatap Muka

1) Kegiatan pendahuluan

Dalam kegiatan pendahuluan, pendidik:

a) menyiapkan kondisi pembelajaran agar peserta didik terlibat baik secara psikis maupun fisik sehingga siap mengikuti proses pembelajaran,

b) mencatat kehadiran peserta didik,

c) menyampaikan tujuan pembelajaran atau SK dan KD yang akan dicapai,

d) menyampaikan cakupan materi dan penjelasan uraian kegiatan sesuai silabus,

e) mengajukan pertanyaan berkenaan dengan pengetahuan yang sudah dimiliki peserta didik untuk mengaitkan dengan materi yang akan dipelajari.

2) Kegiatan inti

Pelaksanaan kegiatan inti merupakan proses pembelajaran untuk mencapai KD yang dilakukan secara interaktif, inspiratif, menyenangkan, menantang, memotivasi peserta didik untuk berpartisipasi aktif, serta memberikan ruang yang cukup bagi prakarsa, kreativitas, dan kemandirian sesuai 
dengan bakat, minat dan perkembangan fisik dan psikologis peserta didik. Kegiatan inti menggunakan metode yang disesuaikan dengan karakteristik peserta didik dan mata pelajaran, yang dapat meliputi proses eksplorasi, elaborasi, dan konfirmasi.

a) Eksplorasi

Dalam kegiatan eksplorasi, pendidik:

i) membimbing peserta didik untuk mendemonstrasikan pengetahuan yang dimiliki sesuai dengan topik/tema yang akan dipelajari,

ii) melibatkan peserta didik mencari informasi yang luas dan mendalam tentang topik/tema materi yang dipelajari dari berbagai sumber belajar dengan memanfaatkan alam dan lingkungan sekitar sebagai sumber belajar,

iii) menggunakan beragam pendekatan pembelajaran, metode pembelajaran, media pembelajaran, dan sumber belajar lain,

iv) memfasilitasi terjadinya interaksi antar peserta didik serta antara peserta didik dengan pendidik, lingkungan, dan sumber belajar lainnya,

v) melibatkan peserta didik secara aktif dalam setiap kegiatan pembelajaran,

vi) memfasilitasi peserta didik melakukan percobaan di laboratorium, studio, atau lapangan.

b) Elaborasi

Dalam kegiatan elaborasi, pendidik:

i) membiasakan peserta didik membaca dan menulis yang beragam melalui tugas-tugas tertentu yang bermakna,

ii) memfasilitasi peserta didik melalui pemberian tugas, diskusi, dan lain-lain untuk memunculkan gagasan baru baik secara lisan maupun tertulis,

iii) memberi kesempatan untuk berpikir, menganalisis, memecahkan masalah, dan bertindak tanpa rasa takut,

iv) memfasilitasi peserta didik dalam pembelajaran kooperatif dan kolaboratif,

v) memfasilitasi peserta didik berkompetisi secara sehat untuk meningkatkan prestasi belajar,

vi) memfasilitasi peserta didik membuat laporan eksplorasi yang dilakukan baik lisan maupun tertulis, secara individual maupun kelompok, vii) memfasilitasi peserta didik 
untuk menyajikan hasil kerja individual maupun kelompok, viii) memfasilitasi peserta didik melakukan pameran, turnamen, festival, serta produk yang dihasilkan.

c) Konfirmasi

Dalam kegiatan konfirmasi, pendidik:

i) memberikan umpan balik positif dan penguatan dalam bentuk lisan, tulisan, isyarat, maupun hadiah terhadap keberhasilan peserta didik,

ii) memberikan konfirmasi terhadap hasil eksplorasi dan elaborasi peserta didik melalui berbagai sumber,

iii) memfasilitasi peserta didik melakukan refleksi untuk memperoleh pengalaman belajar yang telah dilakukan,

iv) memfasilitasi peserta didik untuk memperoleh pengalaman yang bermakna dalam mencapai kompetensi dasar,

3) Kegiatan penutup

Dalam kegiatan penutup, pendidik:

a) bersama-sama dengan peserta didik membuat rangkuman/ kesimpulan pelajaran,

b) bersama peserta didik melakukan refleksi terhadap kegiatan pembelajaran yang telah dilakukan, c) melakukan penilaian terhadap kegiatan pembelajaran yang telah dilakukan,

d) memberikan umpan balik terhadap proses dan hasil pembelajaran,

e) melakukan perencanaan kegiatan tindak lanjut melalui pembelajaran remedial, program pengayaan, layanan konseling, atau memberikan tugas terstruktur baik secara individual maupun kelompok sesuai dengan hasil belajar peserta didik,

f) memotivasi peserta didik untuk mendalami materi pembelajaran melalui kegiatan belajar mandiri,

g) menyampaikan rencana pembelajaran pada pertemuan berikutnya.

\section{METODE PENELITIAN}

Penelitian ini adalah penelitian evaluatif dengan pendekatan deskritif kualitatif. Sumber informasi dalam penelitian ini adalah Kepala Sekolah, siswa atau warga belajar, guru atau tutor Kejar Paket C Harapan Kecamatan Gemolong Kabupaten Sragen. Teknik pengumpulan data yang digunakan adalah teknik wawancara, observasi kelas dan dokumentasi. Teknik analisis data yang digunakan adalah teknik alur yang meliputi pengumpulan data, penyajian data, reduksi data dan penarikan kesimpulan. 


\section{HASIL PENELITIAN}

Berdasarkan uraian-uraian dimuka dan data-data dari hasil penelitian di Kejar Paket C Harapan Kecamatan Gemolong Kabupaten Sragen dapat ditarik kesimpulan sebagai berikut :

\section{Proses Pembelajaran di Kejar Paket}

\section{Harapan Kecamatan Gemolong}

Pelaksanaan kegiatan pembelajaran matematika di Kejar Paket C terutama suasana pembelajaran berlangsung kurang kondusif, hal ini terjadi karena kebanyakan siswa membawa anak-anak ke dalam tempat pembelajaran. Guru menggunakan metode yang monoton sehingga terkesan siswa merasa jenuh. Metode yang digunakan oleh guru hanya metode ceramah dan tanya jawab sehingga kurang memancing motivasi siswa untuk aktif dalam pembelajaran.

Pembelajaran di Kejar Paket C merupakan program khusus yang dirancang guna mencerdaskan kehidupan bangsa dan diperuntukkan bagi warga Negara yang tidak atau belum mengenyam pendidikan formal. Sebagai sekolah yang dianggap asing, pelaksanaan kegiatan pembelajaran matematika berusaha dijalankan oleh guru atau tutor dalam tahap awal. Variasi model pembelajaran yang dilakukan oleh guru masih kurang sehingga terkesan pembelajaran berjalan secara monoton dan membosankan. Guru belum secara khusus menggunakan metode yang dapat menggali kompetensi siswa, hal ini dipengaruhi oleh terbatasnya waktu untuk pelaksanaan pembelajaran.

\section{Pelaksanaan Kurikulum Kejar Paket}

\section{Harapan Kecanatam Gemolong}

Pengelola Kejar Paket C Harapan Kecamatan Gemolong Kabupaten Sragen telah melaksanakan kurikulum pembelajaran matematika di Kejar Paket C Harapan Kecamatan Gemolong telah sesuai dengan petunjuk dan panduan Pedoman Penyelenggaraan Program Paket C Umum sebagaimana diterbitkan oleh Direktorat Pendidikan Kesetaraan. Hal ini dapat diketahui dari hasil supervisi kepala sekolah terhadap pelaksanaan proses pembelajaran matematika.

\section{Kendala-kendala yang dihadapi dalam proses pembelajaran matematika di Kejar Paket C}

\section{Harapan Kecamatan Gemolong}

Kendala yang dihadapi dalam pelaksanaan pembelajaran matematika di Kejar Paket C Harapan Kecamatan Gemolong adalah :

1. Suasana kelas pada saat pembelajaran masih kurang kondusif.

2. Sarana dan prasrana kurang memadai terutama buku pegangan siswa.

3. Variasi model pembelajaran yang dilakukan oleh guru masih kurang.

4. RPP yang dibuat oleh guru kurang lengkap.

\section{Rekomendasi solusi terhadap kendala} yang muncul pada proses pembelajaran matematika di Kejar 
Paket C Harapan Kecamatan Gemolong

Berdasarkan pembahasan dengan berbagai kendala tersebut maka peneliti memberikan rekomendasi usulan solusi atas kendala yang muncul tersebut sebagai berikut:

1. Menganjurkan kepada warga belajar tidak membawa anak-anak ikut masuk ke dalam kelas sehingga tidak membuat suasan menjadi gaduh.

2. Menyediakan buku pegangan siswa untuk proses pembelajaran di kelas Kejar Paket C Harapan, sehingga setiap mendapatkan satu buku.

3. Mengikutsertakan guru atau tutor dalam kegiatan bintek atau workshop yang berkaitan dengan metode dan variasi pembelajaran untuk meningkatkan kompetensi guru yang bersangkutan.

4. Mengikutsertakan guru atau tutor dalam kegiatan bintek atau workshop yang berkaitan dengan pembuatan RPP untuk meningkatkan kompetensi guru yang bersangkutan.

\section{DAFTAR PUSTAKA}

Anonim. 2000 . Undang-Undang Dasar 1945.

Andi Prastowo. 2011. Metode Penelitian Kualitatif. Jogjakarta : Ar-ruzz Media.

Bagus Nugroho. 2010. Analisis Perubahan Kurikulum SMA Mata Pelajaran Matematika di Kabupaten Karanganyar. Tesis.

Djamarah. 2002 . Strategi Belajar Mengajar. Jakarta : Rineka Cipta
Djuju Sudjana. 2006. Evaluasi Program Pendidikan Luar Sekolah. Bandung: PT. ROSDA

E. Baker, B. McGraw, \& P. Peterson. 2003. Evaluation of mathematics education programs. International encyclopedia of education, 3rd Edition. Elsevier.

Howe Kenneth R. 1992 . Liberal Democracy, Equal Educational Opportunity, and the Challenge of Multiculturalism. American Educational Research Journal Fall 1992, Vol. 29, No. 3, PP. 455-470

Karalis Thanassis and Dimitris Vergidis. 2004. Lifelong education in Greece: recent developments and current trends. Int. J. of Lifelong Education, Vol. 23, No. 2 (March-April 2004), 179-189

Malik Ibrahim. (2006). Evaluasi Program Fasilitator Desa Intensif di Kabupaten Kendal. Jurnal Ilmiah Visi PTK-PNF, Vol 1. No. 2. 82-88

Mehmet Bilir. 2007. Non-formal education implementations in Turkey: issues and latest challenges. Int. J. of Lifelong Education, Vol. 26, No. 6 (NovemberDecember 2007), 621-633

Mendiknas. 2003. UU Sistem Pendidikan Nasional no. 20 tahun 2003. Jakarta : Kementrian Pendidikan Nasional.

Mendiknas. 2005. Undang-Undang No. 19 Tahun 2005 tentang Standar Nasional Pendidikan. Jakarta : Kementrian Pendidikan Nasional.

Mendiknas. 2008 . Peraturan Pemerintahm No. 3 Tahun2008 tentang Standar proses Pendidikan Kesetaraan Paket A, Paket $B$ dan Paket $C$. Jakarta : Kementrian Pendidikan Nasional

Muhammad Hasbi. (2006). Evaluasi Penyelenggaraan Program Pendidikan Kecakapan Hidup Dalam Bidang Pendidikan Luar Sekolah. Jurnal Ilmiah Visi PTK-PNF, Vol 1. No. 2. 89-95 
Nusa Putra. 2011. Penelitian Kualitatif Proses dan Aplikasi. Jakarta : PT. Indeks.

Sudjana S. 2001. Pendidikan Luar Sekolah. Bandung: Falah Production.

Tim Dirdik Kesetaraan, 2006. Pendidikan Kesetaraan Mencerdaskan Anak Bangsa. Jakarta: Dirjen Pendidikan Nonformal dan Informal.

Tim Dirdik Kesetaraan, 2009. Petunjuk Teknis Bantuan Sosial Penyelenggaraan Pendidikan Kesetaraan Paket A, B dan $C$ berbasis Komunitas. Jakarta: Dirjen Pendidikan Nonformal dan Informal.

Tim PLSOR, 2007. Panduan Kelompok Belajar Keaksaraan Fungsional. Semarang : Dinas Pendidikan Prop. Jateng.

Tim Penulisan Tesis UNS, 2011. Panduan Penulisan Tesis, Surakarta : Program Pascasarjana Universitas Sebelas Maret
Tjetjep Rohendi Rohidi, 2009. Analisis Data Kualitatif. Jakarta UI-Press.

Wahyudin, 2008. Pembelajaran dan ModelModel Pembelajaran. Jakarta : CV. Ipa Abong.

Wina Sanjaya, 2006. Startegi Pembelajaran Berorientasi Standar Proses Pendidikan. Jakarta : Kencana Prenada Media.

Yana Wardana, 2007. Manajemen Pendidikan Untuk Peningkatan Daya Saing. Bandung : PT Pribumi Mekar. Jakarta : Direktorat Pendidikan Kesetaraan, Dirjen PLS.

Yatim Riyanto, 2010. Metodologi Penelitian Pendidikan. Surabaya: SIC.

Xin Liang, \& Qiong Zhou, 2009. Students experiences of mathematics learning in technology integrated Classrooms. Int. J. of Technology in Teaching and Learning. 5(1), 62-74 